\title{
Study of Urea Treatment of Wheat Straw Fed as Complete Feed on Digestibility of Nutrient of Cross Bred Heifers under Loose Housing System
}

\author{
Vivekin Pachauri $^{{ }^{*}}$, S. K. Mishra ${ }^{2}$, P. K. Mishra ${ }^{3}$, Ashish Tripathi ${ }^{4}$ and Vikas Gupta ${ }^{2}$ \\ ${ }^{1}$ JNKVV- Krishi Vigyan Kendra, Sagar, India \\ ${ }^{2}$ JNKVV - Dryland Horticulture Research \& Training Centre, Garhakota, India \\ ${ }^{3} J N K V V$ - College of Agriculture, Ganjbasoda, India \\ ${ }^{4} J N K V V-K r i s h i$ Vigyan Kendra, Deori, India \\ *Corresponding author
}

\section{A B S T R A C T}

\section{Keywords \\ Urea treatment, Wheat straw, Cow dung, \\ Simplification}

Article Info

Accepted:

26 January 2021

Available Online:

10 February 2021
Limited use of cereal straws in livestock feeding is due to their low voluntary intake, low protein contents and low digestibility. Nutritional value of these roughages can be improved through chemical or physical methods. Efficacy of treating straw with urea for improving its nutritive value is considered equivalent to anhydrous or aqueous ammonia. However, the adoption rate of urea treatment by farmers is low, maybe due to relatively tedious technology and higher requirement of labour. There is need to simplify urea treatment methods.

\section{Introduction}

In developing countries, livestock is usually fed high fibrous crop residues (wheat straw, rice straw, stovers, etc.) characterized by high indigestible fibre due to increased lignification of cellulose. Fermentable energy and protein deficiencies in crop residues coupled with their low digestibility impair intake, ruminal functions, and thus animal productivity. The situation strongly demands the improvement of the nutritive value of high fibrous crop residues through various treatments, for the efficient utilization of existing feed resources. India have a large cattle population, it is very difficult to feed cattle to exploit fully her genetic potentials. Feeding balanced ration in required quantity is the key problem in the area of animal nutrition. Grazing land is negligible, the supply of green fodder is limited in some area. The only feed available for most of the animals in rural areas is poor quality roughages. Complete feed not only provides the required nutrients in proper proportion at a time. Efforts were made in the past to 
improve the digestibility and protein through chemical treatment. In this connection sodium hydroxide was used (Dass and Kundu, 1994) which resulted in improving the digestibility, but its use remained limited due to a high cost of chemical and environmental pollution. The other compound used was anhydrous ammonia (Gotlib et al., 1977) which improved the digestibility and increased the nitrogen contents of the treated straw (Yadav AND Yadav, 1989), but non-availability of ammonia gas in the common market and its transportation through specialized containers limited its use. Lately fertilizer grade urea has been used for this purpose (Ali et al., 1992; Sarwar et al., 2006). Urea is cheaper, easily available and assumed to be equivalent to anhydrous or aqueous ammonia for upgrading cereal straws in the warmer regions of the world. However, the adoption rate of this technique remained low. One reason may be the relatively tedious technology and high requirement of labour. There is a need for the method of treatment to be simplified, with minimum involvement of labour. O'Donovan et al., (1997) reported that the urea treatment process would be popular if it is simple, practical and the material to be used in the treatment is available on the farm. In the present study an effort was made to simplify the conventional urea treatment method by using urease enzyme sources available at the farm, so that farmers could easily adopt this technology. Keeping the views present study was plan with the objective to find out the effect of complete feed "Sani" prepared out of untreated and urea treated wheat straw verses conventional feeding system under loose housing system.

\section{Materials and Methods}

Eighteen cross bred (1/2 Jersy $+1 / 4$ Holstein friesian $+1 / 4$ Gir) heifers between the age of 7 14 months were selected from the Livestock farm, Adhartal, Jabalpur. The average of the three body weight was taken as the body weight of the animal, the heifers were distributed into three treatment groups as per their body weight. Each treatment group had six heifers, treatment Group I was the control, conventional feeding was followed in this group i.e wheat straw adlibitum and $1.5 \mathrm{~kg}$ concentrate mixture per heifers was fed separately. To treatment Group II untreated wheat straw and concentrate mixture in the ratio of 50:50 was fed as "Sani" complete feed and to treatment Group III urea treated wheat straw and concentrate mixture in the ratio of 50:50 was fed as "Sani" complete feed. The respective diets were fed to the heifers for 60 days inclusive of 7 days digestion trial at the end of experimental period.

\section{Results and Discussion}

Digestibility of nutrient - Digestibility of DM in the treatments Groups I, II and III was 49.53 plus minus $0.38,56.23$ plus minus 1.04 and 61.02 plus minus $0.64 \%$ respectively. And the difference is in between the groups were significant $(\mathrm{P}<0.01)$. Lowest digestibility was observed in the conventional feeding system (group I), when complete feed "Sani" (Group II) was used, digestibility was improved and there was further improvement in the digestibility when urea treated wheat straw was used in the complete feed "Sani" (Group III).

Crude protein digestibility was 49.34 plus minus $0.68,57.93$ pus minus $0.5,58.28$ plus minus $\quad 0.32 \%$ respectively. Significant $(\mathrm{P}<0.01)$ lower digestibility was observed in the conventional feeding system (Group I). Digestibility of CP in complete feed "Sani" group II and complete feed "Sani" using urea treated wheat straw (Group III) were superior to conventional feeding system but were at par amongst treatments. 
Digestibility coefficient of EE was 46.60 plus minus $0.68,64.76$ plus minus 1.21 and 65.46 plus minus 1.13 in treatment Group I, II and III respectively.

The differences were significant $(\mathrm{P}<0.01)$. Lower digestibility was observed in the conventional feeding system compared to complete feed 'Sani' using untreated and urea treated wheat straw, which was at par amongst themselves.

Digestibility of CF was57.69 plus minus $0.369,63.22$ plus minus 0.69 and 66.12 plus minus $0.79 \%$ in groups I, II and III respectively. Conventional feeding system Group I showed significantly (P,0.01) lower CF digestibility which was improved when complete feed "Sani" (group II) was used, further improvement in CF digestibility was noted when complete feed "Sani" urea treated was used (Group III).

Nitrogen free extract digestibility percent was 54.12 plus minus $0.46,57.43$ plus minus 0.99 and 58.57 plus minus 0.30 in treatment Groups I, II and III respectively. Significantly lower $(\mathrm{P}<0.01)$ digestibility was observed in conventional feeding system (group I) then compare to complete feed "Sani" using untreated and urea treated wheat straw (Group
II and III) which were at par amongst themselves.

The data of digestibility of different nutrients in different groups indicated that in conventional feeding system, digestibility was appreciably lower than the complete feed "Sani" using untreated and urea treated wheat straw.

Processing of feed "sani" improved digestibility of the different nutrients and further improvement in digestibility of different nutrients were observed when urea treated wheat straw was used.

\section{Feed conversion efficiency}

The Feed conversion efficiencies of heifers fed different diets are presented in table 1. Dry matter required for $1 \mathrm{~kg}$ live weight gain was $8.79,8.64$ and $8.28 \mathrm{~kg}$ for treatment Group I, II and III respectively. The cost per $\mathrm{kg}$ live weight gain for above diets was 26.28 , 27.39 and 26.91 respectively. In the conventional feeding system for $1 \mathrm{~kg}$ of body weight gain, more DM was required when complete feed "Sani" using untreated and urea treated wheat straw was used there was a decrease in DM requirement for $1 \mathrm{~kg}$ gain in body weight.

Table.1 Mean digestibility coefficient (\%) of organic nutrients of experimental diets

\begin{tabular}{|c|c|c|c|c|}
\hline Nutrients & Group I & Group II & Group III & CD1\% \\
\hline Dry matter & $\begin{array}{l}49.53 \text { plus } \\
\text { minus } 0.381\end{array}$ & $\begin{array}{l}56.23 \text { plus } \\
\text { minus } 1.04\end{array}$ & $\begin{array}{l}61.02 \text { plus } \\
\text { minus } 0.642\end{array}$ & 1.73 \\
\hline Crude protein & $\begin{array}{l}49.34 \text { plus } \\
\text { minus } 0.687\end{array}$ & $\begin{array}{l}57.93 \text { plus } \\
\text { minus } 0.575\end{array}$ & $\begin{array}{l}58.28 \text { plus } \\
\text { minus } 0.324\end{array}$ & 1.82 \\
\hline Ether extract & $\begin{array}{l}46.60 \text { plus } \\
\text { minus } 0.689\end{array}$ & $\begin{array}{l}64.76 \text { plus } \\
\text { minus } 1.2\end{array}$ & $\begin{array}{l}65.46 \text { plus } \\
\text { minus } 1.13\end{array}$ & 2.57 \\
\hline Crude fiber & $\begin{array}{l}57.69 \text { plus } \\
\text { minus } 0.369\end{array}$ & $\begin{array}{l}63.22 \text { plus } \\
\text { minus } 0.696\end{array}$ & $\begin{array}{l}66.12 \text { plus } \\
\text { minus } 0.79\end{array}$ & 1.15 \\
\hline Nitrogen free extract & $\begin{array}{l}54.12 \text { plus } \\
\text { minus } 0.469\end{array}$ & $\begin{array}{l}57.43 \text { plus } \\
\text { minus } 0.996\end{array}$ & $\begin{array}{l}58.57 \text { plus } \\
\text { minus } 0.301\end{array}$ & 1.56 \\
\hline
\end{tabular}


Significant $(\mathrm{P}, 0.01)$ increase in the digestibility of DM and CF in group II and III given complete feed "Sani" prepared out of untreated and urea treated wheat straw, over group I respectively were observed. The digestibility coefficient of $\mathrm{DM}$ and $\mathrm{CF}$ in group II and III were also differ significantly $(\mathrm{P}<0.05)$. Processing and blending increased digestibility in group II and it was further treatment of wheat straw improved digestibility of DM and $\mathrm{CF}$ but not of $\mathrm{CP}, \mathrm{EE}$ and NFE over the complete feed fed to group II.

Increase in the digestibility of $\mathrm{CP}, \mathrm{EE}$ and NFE in complete system has been observed earlier by many workers viz; Dien et al., (1990), Jawala (1996), Chaturvedi and Tiwari (1997), Lal (1997) and Patle et al., (1992) and attributed to compounding of roughage and concentrate. Preparation of complete feed "Sani" improved feed efficiency slightly and there was also slight improvement in feed efficiency due to urea treatment of straw.

Higher body weight gain and better feed efficiency have been reported earlier for straw treated with urea by Reddy and Reddy (1983) and Reddy and Reddy (1986). Significantly higher body weight gain in complete feed hava also been reported by Srirammurthy et al., (1992).

\section{References}

Ali, A., Gilani, A.H. and Khan, M.A., 1992. Digestibility of alkali and urea treated straw in sheep. J. Anim. Plant Sci. 2 (12), 19-20.

Chaturvedi, O.H. and Tiwari, A.P. 1997. Performance of cross bred heifers fed urea treated wheat straw stored by three different methods. Indian J. Anim. Production and management. 13: 152-

Dass, M.M. and Kundu, S.S., 1994. Effects of calcium hydroxide, urea and calcium hypochloride treatment on composition and digestibility of wheat straw. Ind. $J$. Dairy Sci. 47 (1), 59-61

Dien, D.L., Pathak, N.N. and Sharma M.C. 1990. Response and arcass characteristics of male murrah buffalo caves fed ration with different concentrate to roughage ratio. Indian J. Anim. Nutr.7(4): 287-290

Gotlib, V.G., Kuzentsova, A.I., Gotlib, G.F., Ushakov, Y.U.A. and Henke, A.N.I., 1977. Digestibility of a diet with ammoniated straw. Nutr. Abst. Rev. 47 (4)

Jawale, S.B. 1996. Effect of compounding of balanced feed on the performance of lactating cross bred cows. M.V.Sc. and A.H. thesis, Ino Vision Pvt. Ltd., Gaziabad, India.

Lal, N.A.K. 1997. Use of diammonium phosphate as phosphorus source in complete feed fed to cross bred heifers. M.V.Sc. and A.H. thesis, JNKVV, Jabalpur

O'Donovan, P.B., Soomro. F.M., Wagennar. J.P., Rehman, S. and Bukhari, F.A., 1997. Urea treatment of straw- Friendly system improved upon in Balochistan. Livest. Res. Rural Dev. 9, 5.

Patle, B.R. Mittal, S.K. and Singh, H.S. 1992. Preparation and evaluation of complete pelleted feed for cross bred heifers. Indian J. Anim. Nutr. 9(1) 26-29.

Reddy, D.N. and Reddy, M.R. 1983. Effect of rations on growth performance and nutrient utilization in growing cross bred calves. Indian J. Anim. Sci. 53: 695-700.

Reddy, G.V.N. and Reddy M.R. 1986. Effect of an hydrous ammonia treatment and processing of whole cotton plants as roughage source in complete feeds for buffaloes. Indian J. Anim. Sci. 58 (1): 93-99.

Sarwar, M., Nisa, M., Hassan, Z. and Shazad, M.A., 2006. Influence of urea molasses treated wheat straw fermented with 
cattle manure on chemical composition and feeding value for growing buffalo calves. Livest. Sci. 105 (1-3), 151-161.

Srirammurthy, K, Das, T. C. and Reddy, M.R.1992. Utilization of forest grass based complete diet in buffalo bulls. Indian J. Dairy Sci. 11: 628.
Yadav, B.P. and Yadav, I.S., 1989. Comparative study of ammoniated wheat and paddy straw on nutrient utilization and rumen fermentation in cattle. Indian J. Anim. Nutr. 6, 215-222

\section{How to cite this article:}

Vivekin Pachauri, S. K. Mishra, P. K. Mishra, Ashish Tripathi and Vikas Gupta. 2021. Study of Urea Treatment of Wheat Straw Fed as Complete Feed on Digestibility of Nutrient of Cross Bred Heifers under Loose Housing System. Int.J.Curr.Microbiol.App.Sci. 10(02): 3328-3332. doi: https://doi.org/10.20546/ijcmas.2021.1002.365 